\title{
Inquiring into the Current Status of Gender Relations in Contemporary Nigeria through an Analysis of the Reception to a Feminist-Oriented \#EndSARS Logo
}

\author{
Oluwafunmilayo Miriam Akinpelu \\ MA in Comparative History, Central European University, Austria
}

\begin{abstract}
Nigeria is one of the many African countries whose contemporary realities have been shaped by globalisation, digital technology, 21st-century wokeness, and the intensification of online activism against several forms of gender and sexual-related discriminations. Based on these developments, it has become necessary to re-assess the current condition of gender relations in the country. This study aims to inquire into the presence of patriarchy in contemporary Nigeria, and explore its divergent manifestations among the country's millennials and Gen Zeds. Knowing that artistic representations offer glimpses into 'received ideas' from a spatiotemporal perspective, this paper focuses on analysing the reception to a graphic logo that was birthed within the larger historical context of the Nigerian \#EndSARS activism. \#ENDSARS was used by Nigerians on social media first in 2017, then rekindled in 2020, to express outrage against the brutal criminal profiling, assault and murder of youths, especially males, by uniformed officers of a Nigerian police unit called the Special Anti-Robbery Squad. During the series of \#ENDSARS protests done in 2020, several transmediatic forms of resistance were harnessed and the logo to be visually analysed was one of the many representative iconographies; it was created by a feminist graphic designer named Ire Aderinokun. While the iconographic logo was projected as an apt symbol of what \#EndSARS signifies, it also generated gender-related controversies that sparked a lot of reactions from Nigerian youths. Thus, it serves well as a referential lens through which the current state of gender relations in Nigeria can be determined and established.
\end{abstract}

Keywords: \#ENDSARS, Feminism, Gender Symbols, LGBTQIA+, Online Activism 


\section{6th International Conference on New Findings On HUMANITIES AND SOCIAL SCIENCES}

\section{Introduction}

Because Nigeria was invented only recently at the whim of the British imperial nation-state during cushioned discussions at the Berlin/Congo conference of 1884-85, where little attention was paid to the vast, ethno-cultural incongruences that characterised the hastily formed territory, there was never a medieval Nigeria (Chamberlain, 1974). There never will be. What existed instead were pre-colonial ethnic groups that formed city-states that can be studied in their own rights. If there is one thing the artificial invention of Nigeria has caused, it is an oblique awareness of gender relations in what used to exist before Nigeria came to be. Hence, while gender relationships and its dynamics are pretty much clear in today's context, with the obvious entrenchment in a patriarchal order that pervades public and private spaces, there is no definitely lucid understanding of gender dealings in Nigeria's pre-colonial past. What is known are the postulations of such scholars like Frederick Engels and Cheikh Anta Diop who asserted that Nigeria and other African societies were not always patriarchal, but were rather matriarchally structured with 'mother-right' at the core of gender operations in ancient, prehistoric times; the patriarchal form of gender relations that currently prevails has been deemed to be " a result of the introduction of external factors like the religions of Islam and Christianity, colonialism, education and others" (Dogo, 2014). Oye Oyewunmi (1998), a historical scholar who subscribes to the myth of matriarchy, categorically claims that there was no concept of gender in prehistoric Nigeria with such ethnic groups as the Yorubas, choosing seniority over gender as their "basic organising principle" (Dogo, 2014).

As it is, the glorious, pre-colonial ethnic-based existences which lacked societally constructed strict gender divides have left no trace in the post-colonial and contemporary Nigerian society. In fact, according to Ogbomo Onaiwu (2005), "contemporary gender relations in Africa [specifically Nigeria] is not a true reflection of women's exercise of power and influence on the continent in the past, today, the marginalised status of women gives the impression that African women have always been oppressed by their male counterparts". Onaiwu's statement truly reflects the replete scholarly studies that have dissected the patriarchal status of contemporary African and Nigerian societies. Not wanting to replicate several works that have touched on patriarchal gender relations in Nigeria, in this study, I will attempt an inquiry into how the current state of genderism in the country manifests itself through public reception to material emblems of gender relations. Given the fact that artistic representations, though subject to stylisation and "conventionalised depictions of idealised subjects", can offer a glimpse into "received ideas" about a particular issue at a particular time, I focus on a single image that show and speak volumes about the workings of patriarchal reimaginings amongst youths in Nigeria (Bleeker et al., 2013). Although I try to avoid the pitfall of synonymising gender with woman-ness which Joan Scott (1986) pointed out, one cannot talk about gender relations in the contemporary Nigerian cultural scene without emphasising the disadvantageous position of women. 


\section{6th International Conference on New Findings ON HUMANITIES AND SOCIAL SCIENCES}

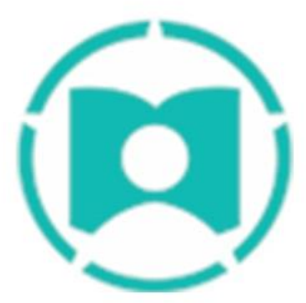

20 - 22 August 2021 Dublin, Ireland

Figure 1: A captured image of males at the Lekki Toll Gate \#EndSARS protest

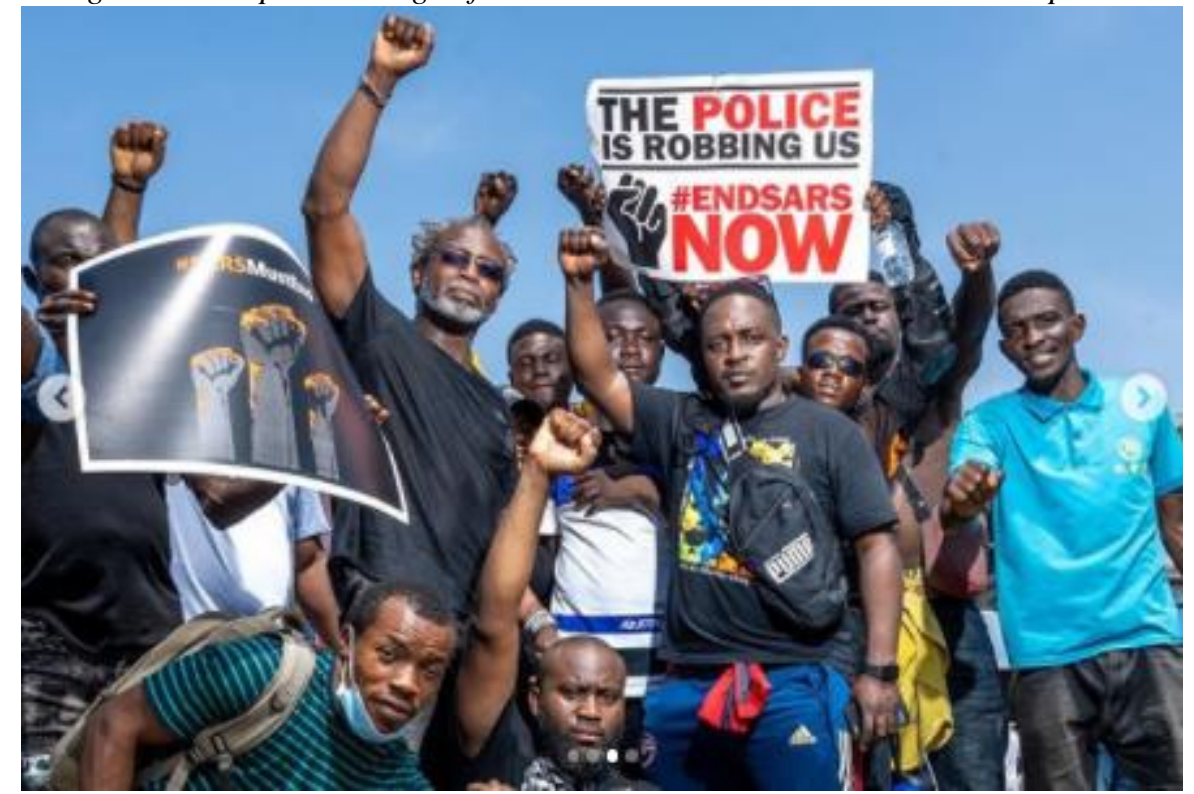

Source: Instagram, (Kelechi Amadi-Obi, 2020).

The image that I reflect on stands as a cultural object framed within the larger historical context of the \#EndSARS hashtag activism and subsequent protests, events that started in 2017 when the hashtag was used by Nigerians on social media to share stories of brutalisations of youths, especially males, in the hands of uniformed officers of a police unit - the Special Anti-Robbery Squad formed in 1992.(Oloyede \& Elega, 2020). Since their formation, extrajudicial killings and the violation of human rights were and are still committed by SARS officials using the excuse of profiling criminals, robbers and internet fraudsters. What seemed to die out at the time was re-ignited when a video of a young man who was allegedly shot by SARS members in southern Delta state and left to die while his car was stolen became widespread on social media (Ukpe, 2020). It caused an outburst of hashtag activism on the microblogging platform of Twitter with \#EndSARS, \#EndPoliceBrutality and \#Sorosoke (Speak Up) trending on the international scene for days. From October 3, 2020, the online activism was moved to the physical, public space as protests erupted in several parts of Nigeria, with the Lekki Toll Gate arena in Lagos being the epicenter from whence Nigerian youths, joined by celebrities and international figures, constantly raised reinvented placards to demand the dissolution of SARS and the possible reformation of the Nigerian Police Force (NPF). After days of concertedly engaging in public marches, protests, civil disobedience and demonstrations to kick against SARS and the proffered replacement - Special Weapons and Tactics Team (SWAT), October 20 became a definite, tragic landmark in the trajectory of the protests, following the mass gunkillings of protesters at Lekki and Alausa in Lagos by an entire army seemingly commissioned by the government. October 20, 2020 has come to be regarded as Black Tuesday. 


\section{6th International Conference on New Findings ON HUMANITIES AND SOCIAL SCIENCES}

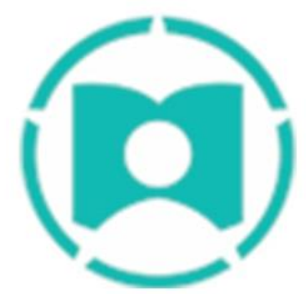

20 - 22 August 2021 Dublin, Ireland

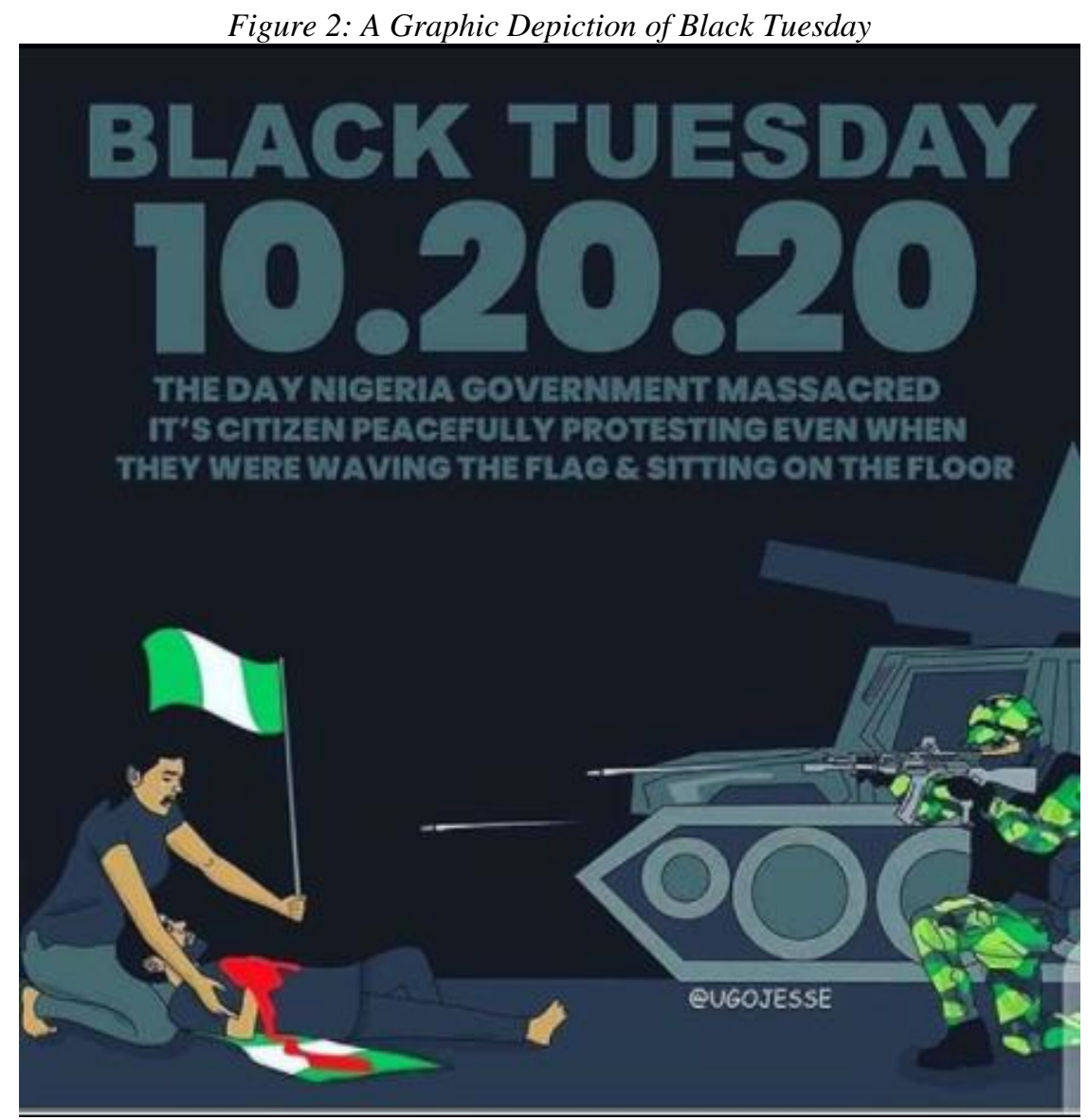

Source: Instagram, (Ugo Jesse, 2020).

Away from the brief contextualisation presented above, \#EndSARS has become a manifestation of how "hashtag activism is important for social transformation... and as such, [how] social media impacts, dictates and influences what the traditional media [thinks is] important to the public" (Oloyede \& Elega, 2020). An aspect of the \#ENDSARS protests which is important to this study is how they yielded a plurality of transmedia experience, in which collective waves of protest materials were displayed through several mediums of expression, like words, images and designs, hacking, material and commodity culture, songs, dance, performance etc. The event whose ember is still stoked till date also became a melting pot that brought together several age-groups, ethnic, religious and interest groups, all of whom crystallised their agitations over police brutality in Nigeria in a way that reflects an Afrofuturistic society that emerges from the realm of the virtual space and finds corporeality in the real world. There are lots of insights to draw from this event. However, in this reflection, 


\section{6th International Conference on New Findings ON HUMANITIES AND SOCIAL SCIENCES}

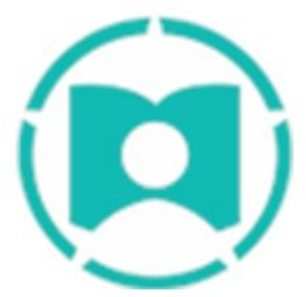

20 - 22 August 2021

Dublin. Ireland

I concentrate on a visual analysis of the reception to a yellow-black \#EndSARS logo which is one of many visual representations created in the heat of the protests. This logo was and still is proliferated as an apt symbol of what \#EndSARS signifies. In this study, I use this image as a representative source of reference in my attempt to inquire into the gendered visual culture of today's Nigeria.

\subsection{The Controversial Feminist-Oriented \#ENDSARS Logo}

Figure 3: The Feminist-Oriented \#ENDSARS logo to be used in this study

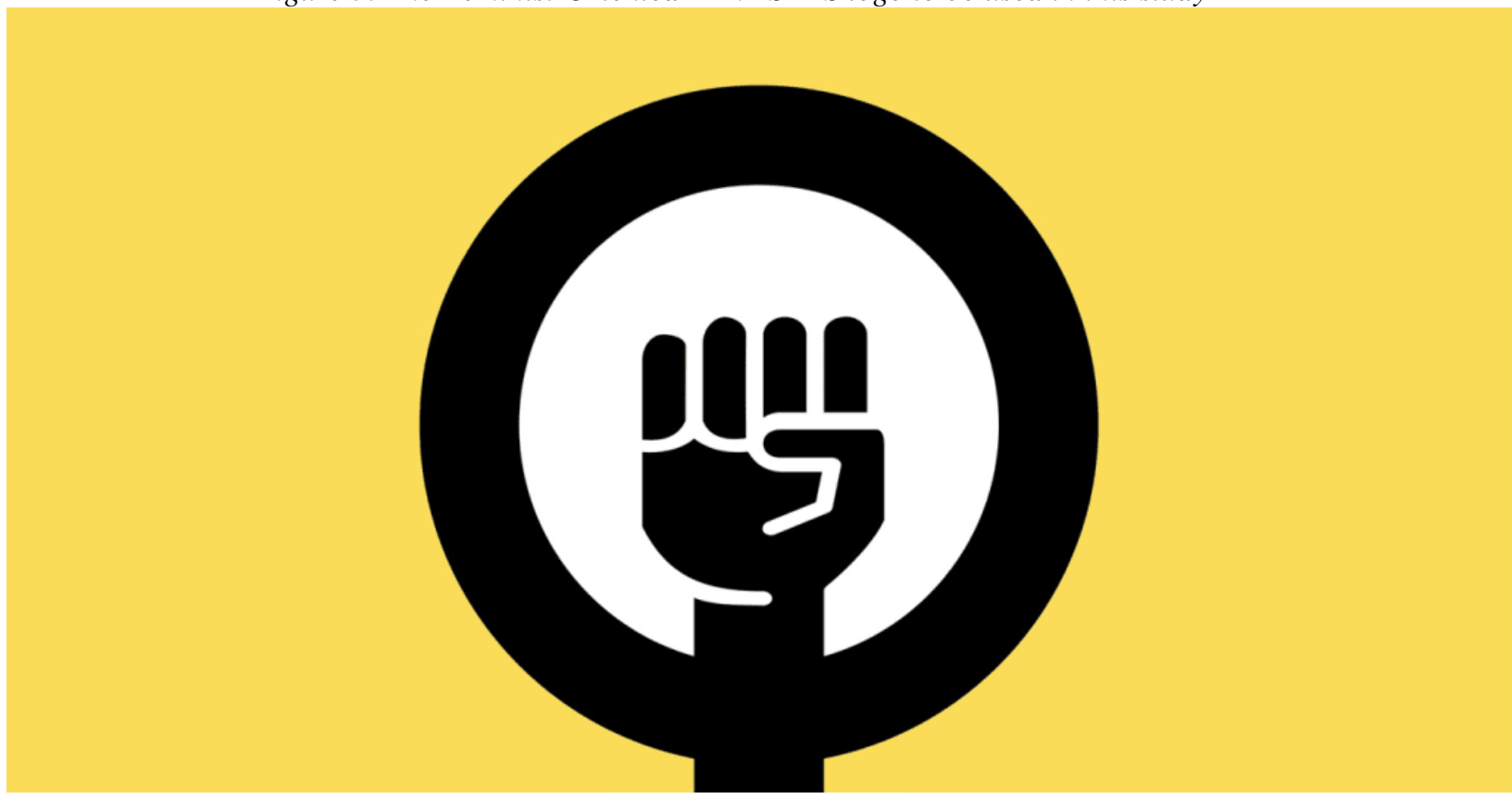

Source: Twitter, (Ire Aderinokun, 2020)

The logo which visually comprises a black fisted hand inside a black-white circle resting against a yellow background was designed by Ire Aderinokun, a Nigerian lady who shared it on Twitter only to have it become increasingly popular amongst Black Twitter users who put it up as their avatars and profile pictures. Following its popular use on social media and even on placards in physical protest grounds, Aderinokun shared a tweet on October 23rd, 2020: "On another note, it was honestly so heartwarming to see how this logo I designed in less than 30 minutes and under so much pressure became such a powerful symbol in the movement Yellow heart + it was hilarious that misogynists thought the female symbol in it was "hidden." It so happened that, due to the size properties of Twitter, the very-significant cross at the bottom of the logo got cropped out so that what is being shared across platforms by people is only 'half the logo' and not the full image. That the designer starkly pointed attention to the sign at the bottom which is clearly a representation of the traditional female symbol changed the perception of many about the logo and stirred full-on gender-related discussions within the context of the \#EndSARS protest. The fact that she added these words, "Men are so pained about this female symbol. I love to see it [sic] Face with tears of joy" generated more criticisms 


\section{6th International Conference on New Findings ON HUMANITIES AND SOCIAL SCIENCES}

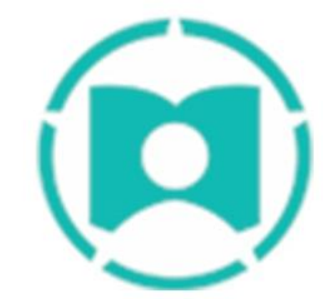

20 - 22 August 2021

Dublin. Ireland and agitations (Okonjo, 2020). Several tweeps were upset about the seemingly disruptive nature of adding a feminist emblem to what is supposed to be the defining logo of a 'genderneutral' movement.

The addition of the female symbol to the \#EndSARS logo which, no doubt, gives rise to the inference that the closed fist, in fact, belongs to a woman, was deemed by Twitter users as unnecessary, a clout-chasing move, and purely narcissistic on the part of the designer. Such a user as @ acaiafas nicely put forward a disagreeing opinion: the "+ wasn't necessary. This isn't and was never a feminist movement; it was a collective goal we all fought for both male and female. Let's not make it about gender please. Let not your good be ill-spoken of!" (Okonjo, 2020). On the other hand, Queen Nwokoye, a celebrity figure, vehemently expressed displeasure with these words: "This is what I hate about these fake twitter feminists who obviously don't know what feminism is all about. Being bitter, quarrelsome, hateful and outrightly foolish does not make you a feminist. It makes you a sick person. Bringing up gender war now is your agenda right?" (Okonjo, 2020).

Figures 4-5: Other comments and reception to the logo

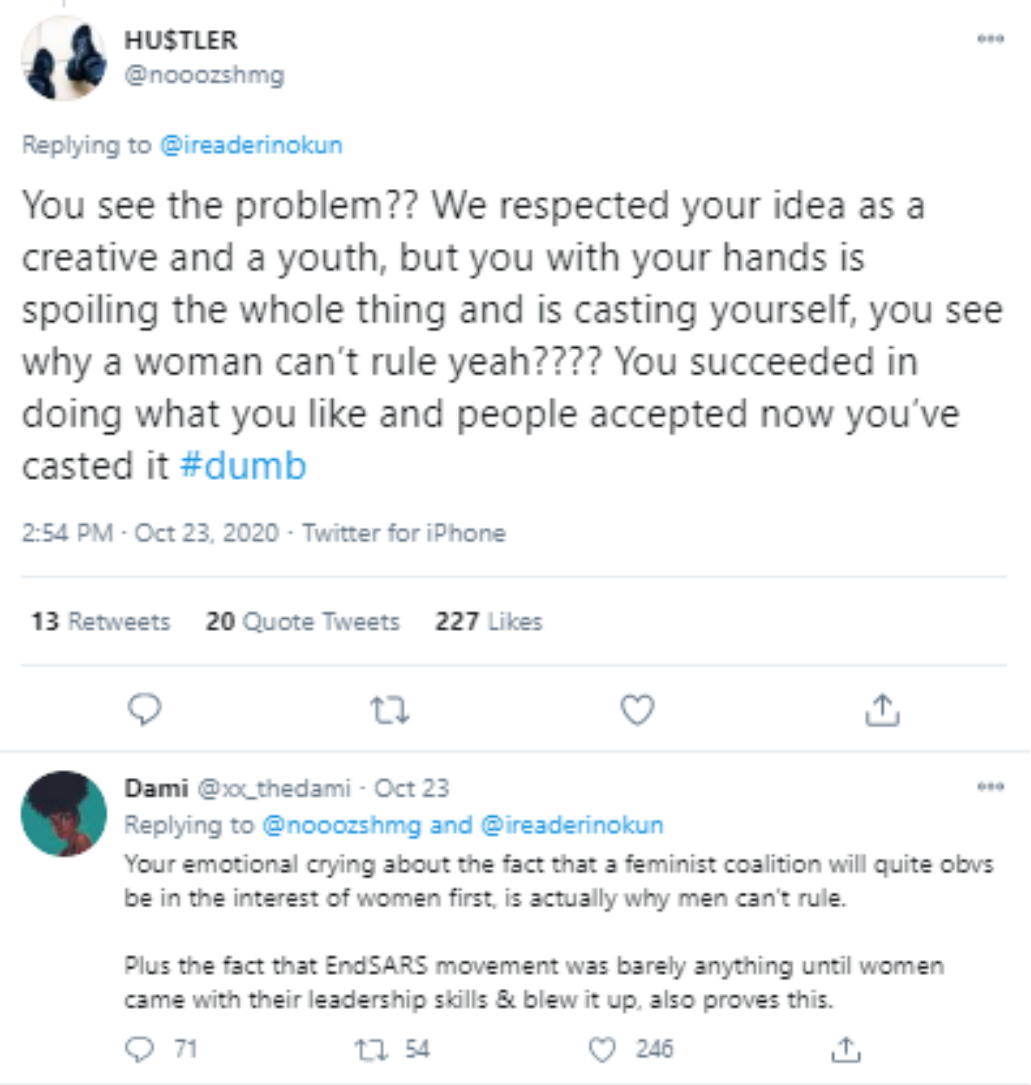

Source: Twitter, (HU\$TLER, 2020) 


\section{6th International Conference on New Findings ON HUMANITIES AND SOCIAL SCIENCES}

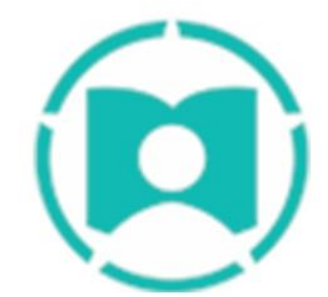

20 - 22 August 2021 Dublin, Ireland

\footnotetext{
ap

Acell I \#EndSARS

@OceeAnaeme

Replying to @ireaderinokun
}

Wow are you okay, we've not question the symbol.

Never intended to. Feministic or not, never mattered to

us. Man or woman, we both were victims of brutality and death. Why this coming when we supposed to be United more than ever. Even the statue of liberty is a woman, who cared?

5:13 PM - Oct 23, 2020 - Twitter Web App

3 Retweets 1 Quote Tweet 95 Likes

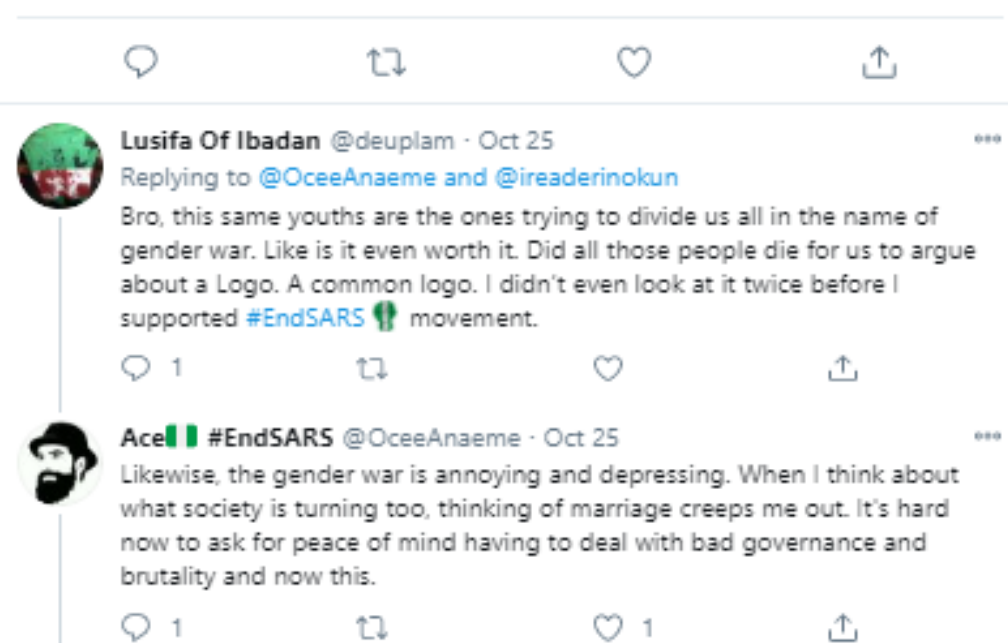

Source: Twitter, (AceNG\#EndSARS, 2020)

This \#EndSARS logo and the several panicky reactions about how it threatens to start a 'gender war' makes for an interesting study especially in light of recent explorations of how the visual form is used and received in public engagements. Lesley Cowling and Carolyn Hamilton (2020) did indeed weigh in on "the capacity of visual forms to precipitate public critical engagements, through the interplay among their form, content, genre and the conditions of their circulation". One of the most important sites of interplay is citizens' interactions and actions in socially-charged engagements within the public space; thus, it is important to situate "audiences within this context of a mediated... civic space" that have been "infiltrated by visual representations that are imbued with discourses about the global... and "the distant" (Ademolu, Edward Adedamola Adeleke, 2018). This is what the analysis below intends to weigh in on. 


\section{6th International Conference on New Findings ON HUMANITIES AND SOCIAL SCIENCES}

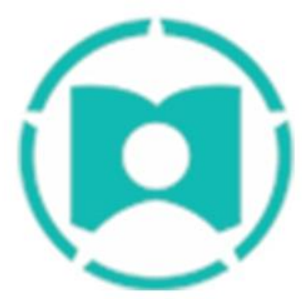

20 - 22 August 2021

Dublin, Ireland

\section{A Gendered Analysis of the Reception to the Feminist-Oriented \#ENDSARS Logo}

The image act is understood as the effect on sensing, thinking and acting that arises from the power of the image and the interaction with its looking, touching or listening counterpart (Bredekamp, 2013).

Figure 6: Protesters holding up placards showing feminist-oriented \#ENDSARS logo

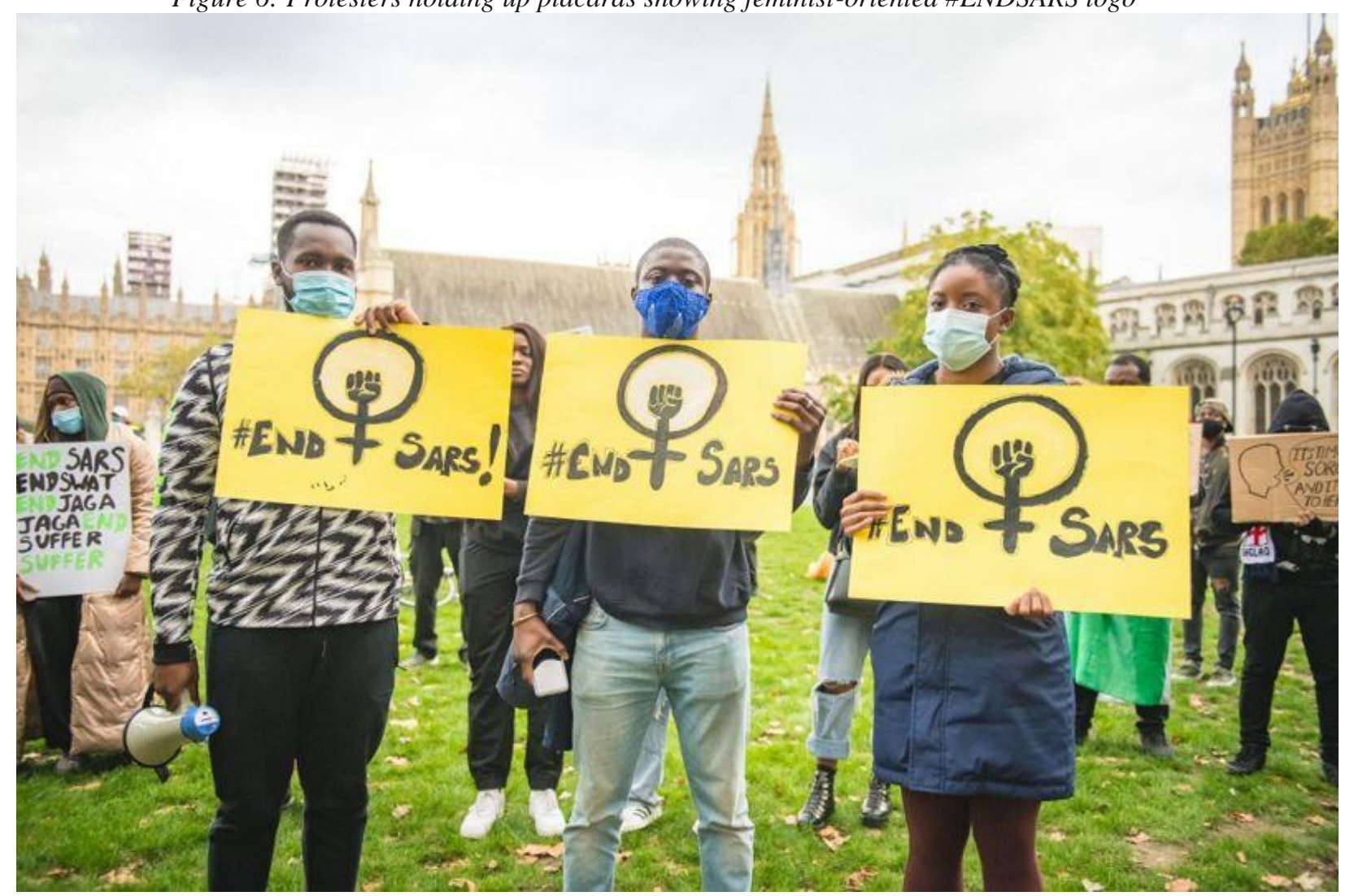

Source: BBC News, (“Nigeria's End Sars Protests, in Pictures,” 2020)

Although the \#ENDSARS logo in itself does not offer clear information, the leverage it presents is that it is framed within a deeply-historical context; hence, it does not only offer a perceived idea of what constitutes the hotbed of gender discussions in this context, but through the advantage of social media engagements, there is access to real-time, immediate reactions and comments with which the received ideas portrayed in the image can be framed. To start with, a cursory understanding of the context around which the logo was created reinforces claims about the largely ignored, less-acknowledged roles of women as "creators of images" who should be credited for their works rather than "consumers and patrons of art objects" (Bleeker et al., 2013). According to Ogege Omadjohwoefe (2011), "the culturally constructed gender differentiation into masculinity and femininity... is most fundamental in defining what role males and females play in society. The roles played by males are highly valued and rewarded than that of females" (Omadjohwoefe, 2011). Aderinokun, being the creator of the logo above, received a fair share of criticisms due to her gendered identity as a woman and her 


\section{6th International Conference on New Findings ON HUMANITIES AND SOCIAL SCIENCES}

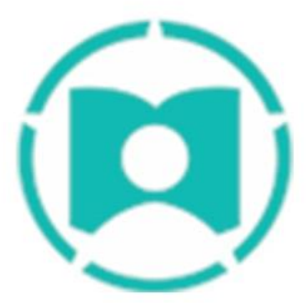

20 - 22 August 2021

Dublin. Ireland ideological stance as a feminist. It is due to her projected conviction that feminists be allowed a distinct voice in what has been categorised as a protest that predominantly concerns males (who are considered the main victims of SARS officials), that she is trolled on social media. This is despite the fact that women and LGBTQIA+ individuals have also been SARS victims, with some of them beaten to a pulp, sexually abused, and even raped (Ndifon, 2020). Some of her trolls particularly singled her out as a microcosmic example of the insensitivity and ineptness of women in the face of national crises.

This, thus, reflects a hegemonic power-play within the site of protest called \#EndSARS, with some (not all) angry, male protesters putting it out there that a chunk of the \#EndSARS space of activism is their territory and should not be 'maligned' by the presence of alien, female bodies such as an incorporation of a traditional female symbol or feminine closed fist. This condemnation of feminine invasion into a supposedly masculine protest space also found projection in the reaction to the responsive action of a female performing artist and disc jockey, DJ Switch, during the killings of October 20, 2020. Due to the measures taken beforehand to cut off electricity and internet connectivity, DJ Switch was one of the very few (if not the only one) able to capture the atrocities committed by military officials by recording an Instagram live video on her phone which gained traction on social media. Due to her agency as a creator of material evidence, she was praised by many for her act of bravery, especially women on social media, but also criticised or even threatened by some males who felt slighted by her role as a forerunner of never-before-known information. Recently, it was said that she was granted asylum by Canada and this led to more provocations on the part of men who saw her as more of an instrument of discord or a criminal than a survivor of a spray shooting attack on protesters verified by social media, international media houses and NGOs (Amnesty International, 2020).

Figures 7-8: Images showing attack on female DJ after she did an Instagram live confirming Black Tuesday incident
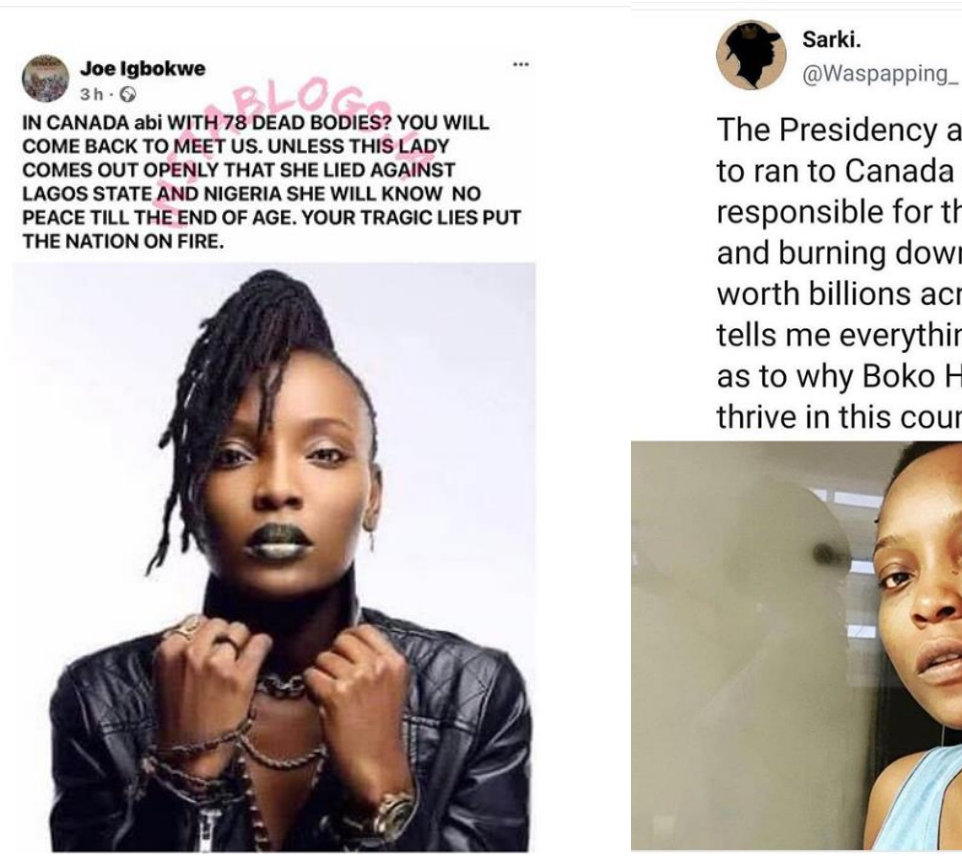

The Presidency allowing DJ switch to ran to Canada after being responsible for the lost of lives and burning down of properties worth billions across the country tells me everything I need to know as to why Boko Haram continue to thrive in this country.

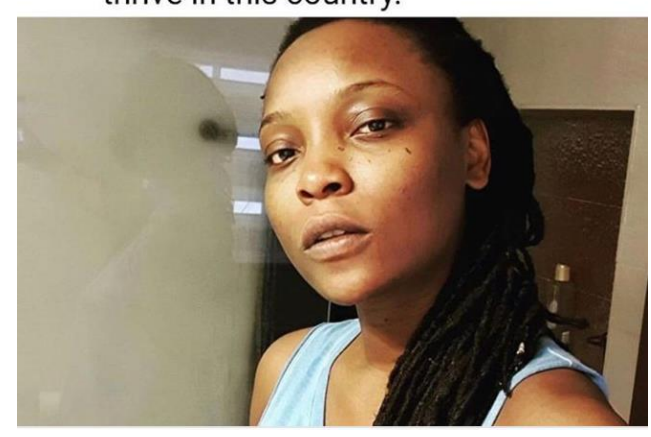




\section{6th International Conference on New Findings ON HUMANITIES AND SOCIAL SCIENCES}

Source: Instagram, (Instablog9ja, 2020)

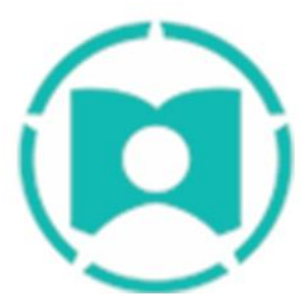

20 - 22 August 2021 Dublin, Ireland

Similar to this is the fair share of criticism that Aisha Yesufu, an unforgettable face of the \#EndSARS protest in Lekki received; although she was praised for the most part, she was also criticised for deviating from Islamic injunction of obedience and propriety just as some inferred that she was promoting her own (non-Islamic, feminist) agenda (ASM, 2018).

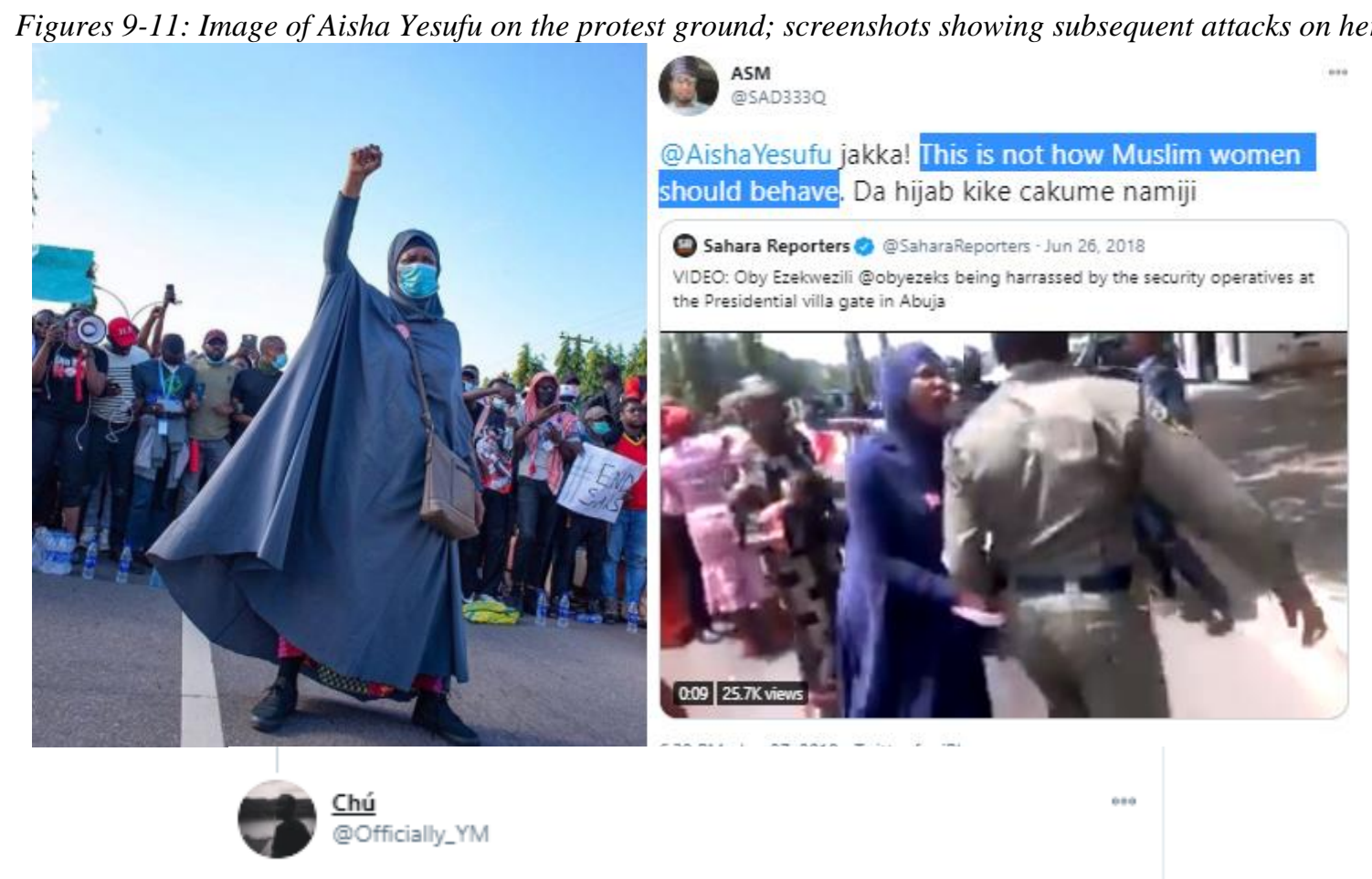

Replying to @dashmya and @AishaYesufu

Her action is an insult and a mockery of the hijab. Part of the attributes of the hijab is MODESTY, MORALS and DECENCY, of which none of those was displayed over there. Next time remove the hijab and tie it round your waist $\mathrm{Ma}$, then the police will know you're not joking.

Sources: Twitter, (Aisha Yesufu, 2020; ASM, 2018; Chú, 2018)

These examples reflect strands of the argument presented by Oyewunmi that the category of gender signals a site of visual mechanism that yields both cognitive and reactionary convictions. One who identifies with the female gender is perceived as a "woman of body" while the male-gendered person is projected as a "man of reason" (Dogo, 2014, p. 270). Thus, there seem to be a general subscription to the conception that a woman is subject to passion and irrationality and cannot be relied upon for factual reportage in such a chaos-ridden situation as in the case of DJ Switch or made to lead a movement (as Aisha Yesufu is successfully doing). This is contrasted to a man who operates with his intellect and is thus better suited to be a symbol or prominent figure in any form of activism. This suggests that there is a perceived, 


\section{6th International Conference on New Findings ON HUMANITIES AND SOCIAL SCIENCES}

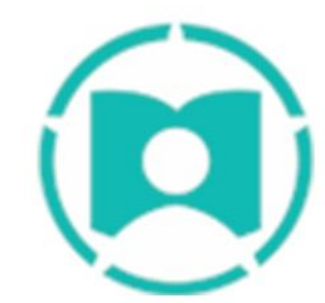

20 - 22 August 2021

Dublin. Ireland unconscious demand for masculine authentication before real, action-embodying agency can be granted to the activities of women on a protest field.

Furthermore, what reifies this hegemonic dialectic of woman of body and man of reason is the reaction of women and professed feminists to the male-centered narrative surrounding SARS victimisation. Rather than assume a position of female inclusivity, there has been a widespread acquiescence (albeit aggressive) to the portrayed SARS-based narrativisation of males being oppressed by males. For one, some women urged true feminists to refrain from participating in the protests as it would be 'blasphemous' to render support to the male counterparts who, in fact, are not worthy of being 'assisted'. Others mocked the males for not being able to take charge of the issue confronting them, with such a comment as this coming from Margarita Mama @ TheBaejiri (2020): "You guys correct me if I'm wrong, but are you saying patriarchy FC had the money and time to register a domain but for the \#EndSars 1 movement, we didn't hear anything from them, even though men are usually the ones targeted by SARS? It's the feminists that rescued them?"

Hence, while it would seem that there is a superficial projection of gender neutrality on the front scene of the protests, there is an underlay of gender dichotimisation fraught within the movement. This, thus, indicates that there is indeed a stark "gender agreement of representation" amongst Nigerians. Paradoxically, though, this agreement is located within the notion of difference. This is just as Whitney Davis (2003) puts it: "the marking of gender difference depends on and can generate an extensive and complex systematicity through agreement. In this way, elements of the representation that do not depict a sex, such as nonhuman or inanimate things can [or cannot] be gendered". What is meant by this is that, within the Nigerian contemporary space, the socially-differentiated gender binaries between males and females have been considered normative and binding by Nigerians themselves, such that their inflections of ideologies and movements like feminism or anti-feminism still reflects this agreement on genderism and role-differentiations. The Nigerian gender of representation also clearly reveals the perceived superiority of men holds a firm, agreeable grip on many, thus reinforcing the operation of patriarchy. Through the agreed representative perception that there is a stark difference between Nigerian men and women, with each gender trying to mark their territories and fight for right only within the perimeters of their different realms, there is a normalisation and reification of patriarchal practices emblazoned by the male gender which might be aggressively opposed but is still agreed upon to be the norm by the female counterpart. It is interesting that in this normative, divisive perception of gender, there is no room for 'middling'; for having any other gender identity apart from male or female. The social construction of differentiated yet agreed-upon gender identities has given rise to an equally formidable agreement-based patriarchal system of operation with regards to sexuality. As put forward by Otutubikey Izugbara (2004), the "prevailing codes of sexuality and sexual conduct in contemporary Nigeria are socially produced and fed by oppressive patriarchal subjectivities and ideologies that try to instil a sense of what is normal sexually-speaking, for us all".

Relatedly, it is clear that the positionality of women in the private, domestic space seeps into the agitations of males who are responding to the efforts of Nigerian young women to break 


\section{6th International Conference on New Findings ON HUMANITIES AND SOCIAL SCIENCES}

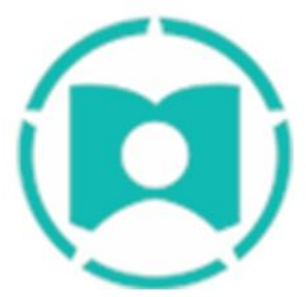

20 - 22 August 2021

Dublin. Ireland through locational restrictiveness. It is against this reinforcement of patriarchy through an "agreement about differences" that projected counter-representations of what should, in fact, be used as \#EndSARS logos are not surprising. Below is a designed logo pitched to Google as a possible Doodle that can be used in a shared campaign of solidarity for the \#EndSARS movement. One thing that becomes immediately obvious is the masculinised depiction of the closed fist in the image:

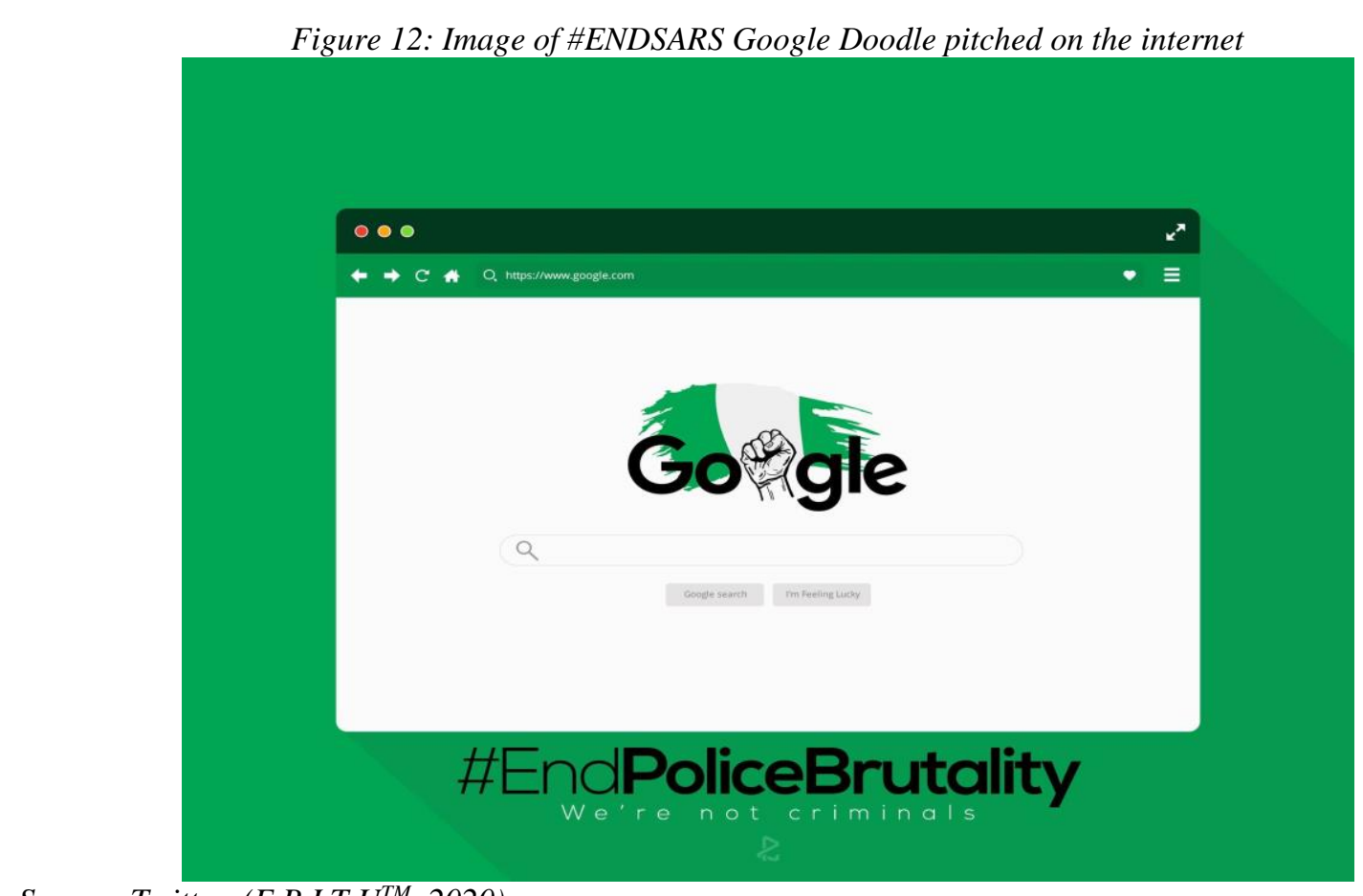

Source: Twitter, (E B I T U U ${ }^{T M}$ 2020)

This is not to say that there has been no gender-neutral logos and designs in the entire graphical oeuvre of the movement but the contestation over the logo designed by Adenirokun and the consequent battering on social media about who and what group should be included in the identity rhetoric of the EndSARS movement has shown that Nigeria's pensive, dichotomous gender representations cannot be extricated from issues of national importance, whether in the private or public space.

\subsection{The Visual Re-encoding of Traditional Gender Symbols}

The historicity of the traditional female symbol used in the logo under discussion bears significant import. Contrary to the biblical-based artistic representations of women like the Virgin Mary and Mary Magdalene as dwelt upon by Bleeker et al., this female symbol with the cross which is highly promoted during International Women's day(s) and in several feminist- 


\section{6th International Conference on New Findings ON HUMANITIES AND SOCIAL SCIENCES}

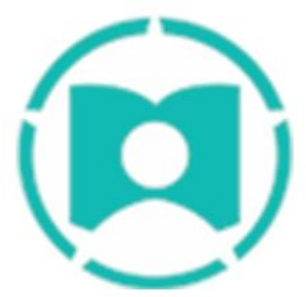

20 - 22 August 2021

Dublin. Ireland oriented activities has a scientific ontology. It is significant how the symbol was first used by scientists to denote sexes of plants, and subsequently, human patients. This use of semiotic inscriptions rather than full-body image representations would suggest an alternative resort to science rather than religion in marking sexual differences. But is this really the case. A certain Joseph Justus Scaliger "speculated that the male symbol is associated with Mars, the god of war, because it resembles a shield and spear; and that the female symbol is associated with Venus, goddess of beauty, because it resembles a bronze mirror with a handle" (Elyse, 2013). If this is truly the case, then the argument that science often appeals to already-established religious myths is even more valorised. Besides, this scientific emblazoning of the sexual symbols of male, female (and hybrid in the case of plants), clearly marks a validation of the biological deterministic criterion in the rendering of gender relations. This is, no doubt, related to how science is used as a category to justify gender and racial bias or the supposedly 'natural' phenomenon of heterosexuality.

Figures 13-14: Traditional gender symbols
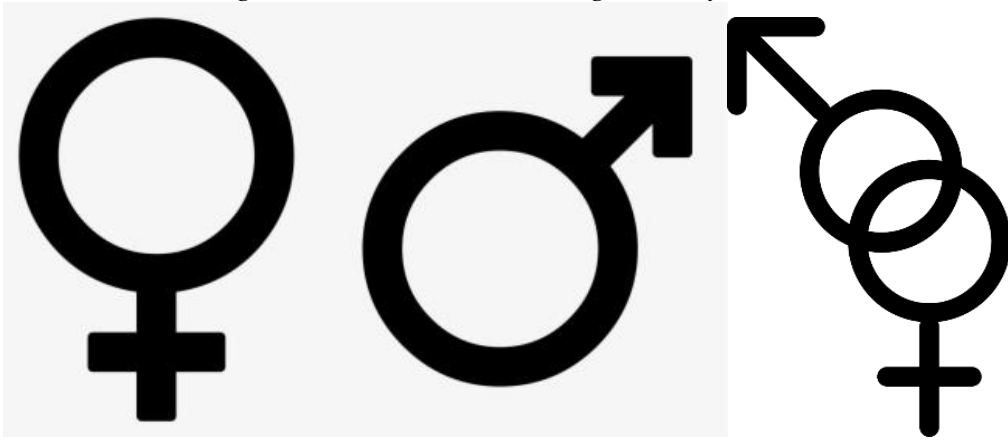

Sources: Web page, (Dreamstime)

However, in recent scholarship and 21st-century LGBTQIA+ activism, there has been an appropriation or re-encoding of the symbols as indicators of reconfigured sexual orientations; these reconfigurations are usually used especially within sites of protests.

Figure 15: Image showing a re-encoding of traditional gender symbols to reflect divergent sexual orientations

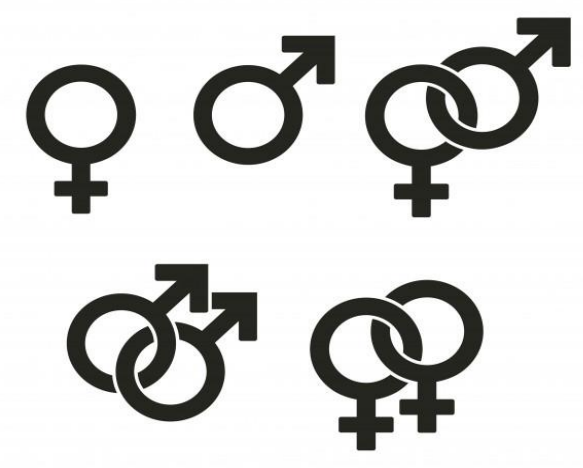

Sources: Web page, (Dreamstime) 


\section{6th International Conference on New Findings ON HUMANITIES AND SOCIAL SCIENCES}

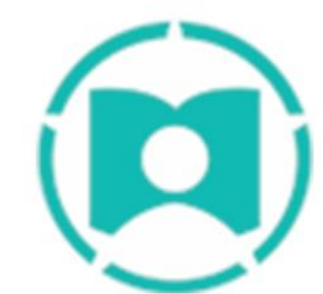

20 - 22 August 2021

Dublin, Ireland

In the case of this study, (also, it has to be said that) by radically appropriating the use of the traditional, hetero-normative female symbol in the context of what is deemed as a male space of contestation, Aderinokun carved a space for the inclusion of females, and thus, engendered a subscription to gender equity even within the sphere of online activism. She, thus, repurposed the symbol and rebelled against the pervading narrative both in medieval Europe and contemporary Nigeria in which the image representation of "the female body" is merely an objectification of its corporeal "reproductive and erotic potential, and the need for its care and control", a narrative which put considerable "limitations on women's autonomy and actions" (Bleeker et al., 2013, p. 213).

\subsection{The Unsung Voices of \#ENDSARS: Oppositions against LGBTQIA+ Inclusion}

Beyond the antipathy that feminist inclusivity received as shown through the reception of the logo, the protest period revealed the more dissenting, negative lethargy of Nigerians with regards to the inclusion of other gender identities that do not belong to the binarised, differentiated categories of male and female. An organisation called Feminist Coalition (Twitter name: @feminist_co) was called out by Nigerians in this respect. The online activist group was and is still highly instrumental to the donation campaign started on October 9 by a Nigerian lady Feyikemi Abudu in the heat of the campaign; a campaign which yielded millions of naira that were disbursed to several agencies which were used to supply protesters with food, water and provisions, and subsequently, to take care of injured victims after the mass shooting on October 20. Although their efforts were really appreciated by the Nigerian online community, a couple of tweets made by the organisers about LGBTQIA+ inclusivity in the interest groups that make up the \#EndSARS movement provoked agitation within the protest community on and beyond Twitter:

Figure 16: Feminist Coalition shows solidarity for LGBTIQ+ inclusion in \#ENDSARS protests 


\section{6th International Conference on New Findings ON HUMANITIES AND SOCIAL SCIENCES}

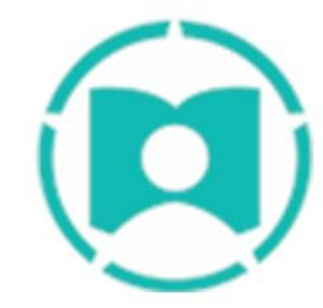

20 - 22 August 2021

Dublin, Ireland

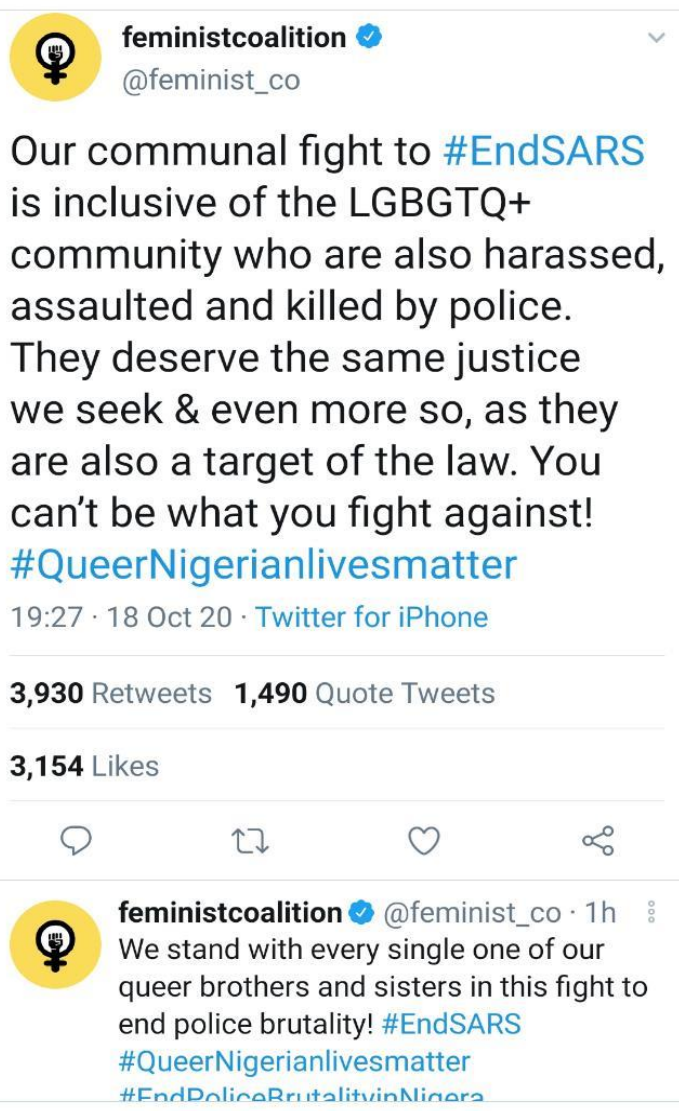

Source: Twitter, (Feminist Coalition, 2020)

Based on real-time responses from Nigerian youths, it is obvious that many felt that the inclusion of the LGBTQIA+ community inferred that the protest is being hijacked by an overtly-feminist cult with their own agenda. However, some reasoned that although it might be reasonable to include the queer community due to how they also face harassment in the hands of SARS officials, ${ }^{1}$ given the Nigerian context and the still-operational Same-Sex Prohibition bill, including them will create divisions and thwart the purpose of the protest as the community will not be accepted by participant religious, age and ethnic groups (Giwa et al., 2020). Reflecting on this, it would seem then that, amidst the advocacy for national freedom from police brutality, there is a wave of grassroot oppression perpetrated by citizens to citizens in the contemporary Nigerian society; the country is riddled with what Foucault presented as subjugated power-relations at local levels, in so much that there is the pervading presence of "oppressive, male-biased discursive subjectivities [that are]... homophobic (i.e. support the hatred and fear of men who step out of or challenge traditional male roles)... penis-centred (i.e. glorify and idolize traditional imageries of masculinity and male sexual prowess and encourage

\footnotetext{
${ }^{1}$ Several studies have delved into the police brutalisation of the LGBTIQ+ community in Nigeria. Giwa et. al emphasised that members of this community have been subjected to "arbitrary arrest and unlawful detention, invasion of privacy, physical assault and battery and blackmail, extortion [and] top human-rights violations and abuses [by] police state actors".
} 


\section{6th International Conference on New Findings ON HUMANITIES AND SOCIAL SCIENCES}

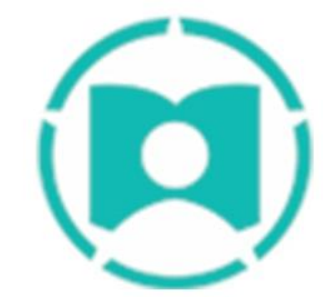

20 - 22 August 2021

Dublin. Ireland

the objectification of women and their body), and... male-privileging" (Izugbara, 2004). Some of the antagonistic comments made have been presented below:

Figures 17-20: Tweets showing different reactions to LGBTQIA+ inclusion in \#ENDSARS protests

\section{$\leftarrow$ Thread}

SEGA L'éveilleur $\odot$ 을

@segalink

Kindly call this what it is. This is NOT \#EndSARS $\mathbf{B}$ Movement but an LGBTQ+ and Feminist Movement. Stop impersonating \& exploiting the vulnerability of Nigerians, who genuinely wants to end impunity. This agenda is dead on arrival. There is no place for insurrection in Nigeria! twitter.com/feminist_co/st...

This Tweet is unavailable.

Source: Twitter, (SEGA L'éveilleur $\left.{ }^{\circledR} \square, 2020\right)$

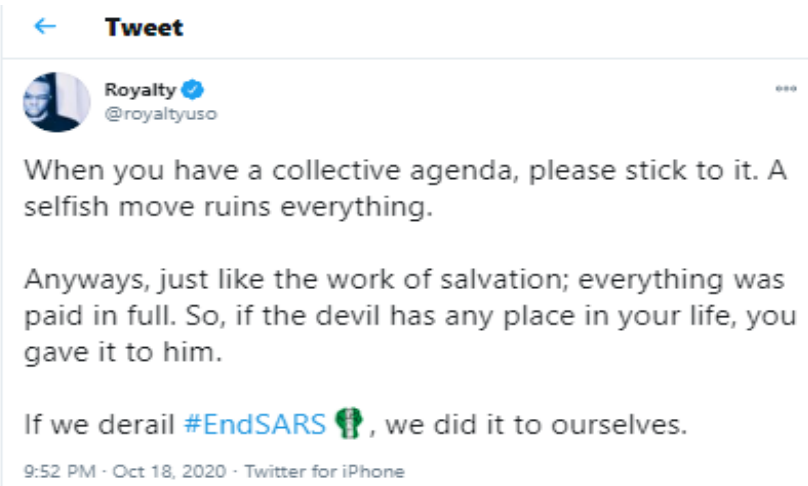

Source: Twitter, (Royalty, 2020) 


\section{6th International Conference on New Findings ON HUMANITIES AND SOCIAL SCIENCES}

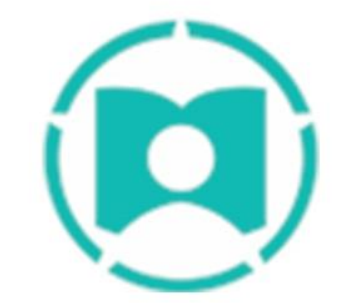

20 - 22 August 2021

Dublin, Ireland

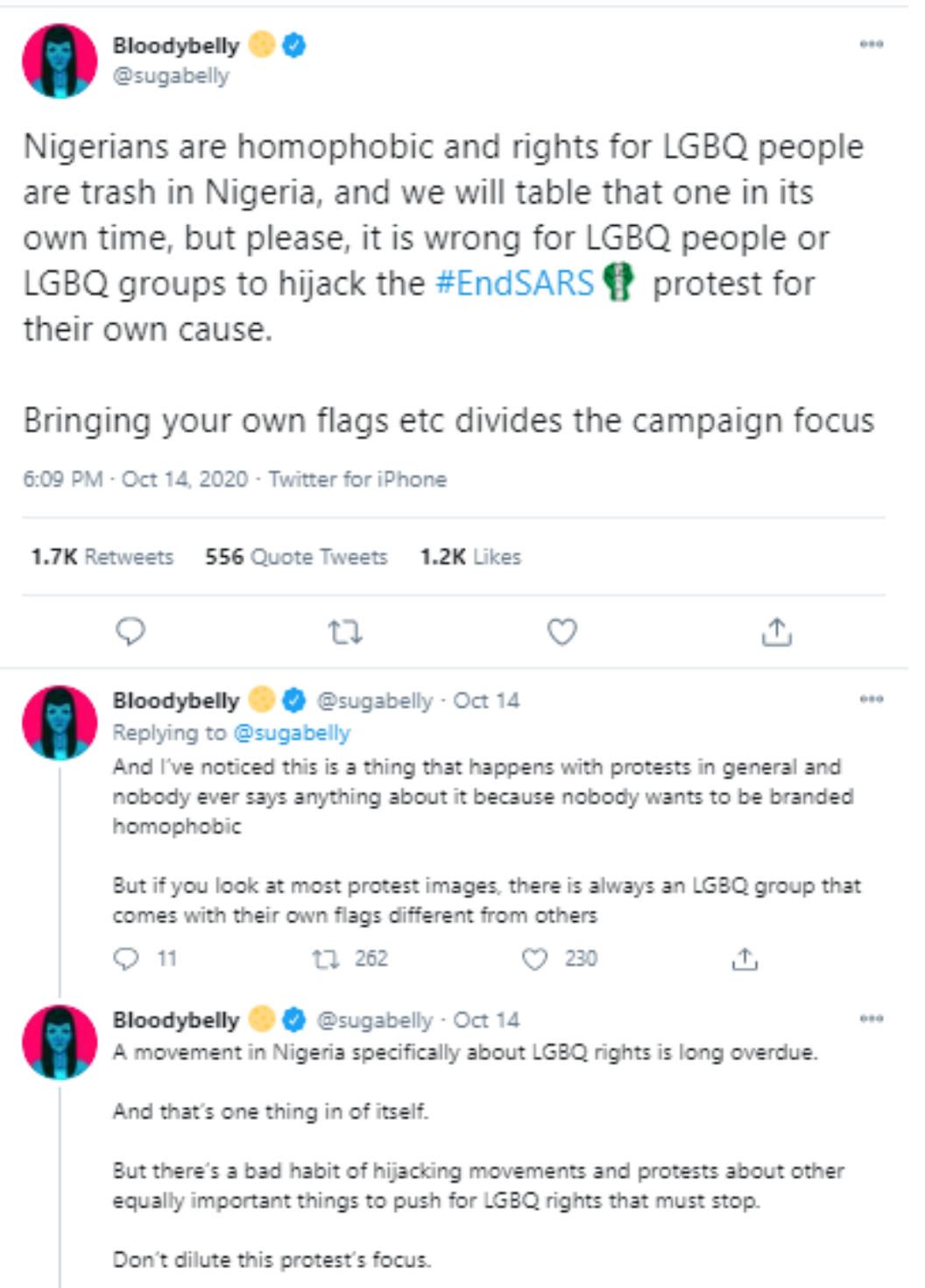

Source: Twitter, (Bloodybelly O, 2020)

Following the outrage their tweets generated, Feminist Coalition deleted the posts and, instead, stuck to making EndSARS related statements that appealed to the good will of everyone with its inclusion of the binary gender categories - man and woman - recognised by the Nigerian community: 


\section{6th International Conference on New Findings ON HUMANITIES AND SOCIAL SCIENCES}

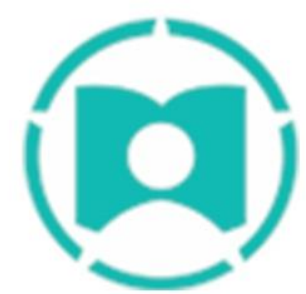

20 - 22 August 2021

Dublin, Ireland

Figure 21: Feminist Coalition replaced former statements with a new, gender-binarising statement

Source: Twitter, (Feminist Coalition, 2020)

The feminist coalition demands the disbandment of the SARS unit and an end to the predatory harassment, intimidation and physical \& sexual violence millions of Nigerian men and women face at the hands of the police.

\section{\#EndSARS \#EndPoliceBrutality}

@feminist_co
(1) feministcoalition2020.com

(1)

It is quite interesting, however, that up till date, @feminist_co uses the much-contested logo as its profile picture and the colour yellow as its avatar on Twitter. This reveals an attempt to subvert the stereotypes and antagonism directed at them for their support of LGBTQIA+ while, at the same time, acquiescing to the gender norm and prevalent social construct(s) in the Nigerian society. Despite their acquiescence, the organisation has remained active in the rendering of support to victims affected during the \#EndSARS protests which went from being peaceful to being a playground for the exhibition of brutality and governmental oppression. Reflecting on the ongoing role of the Feminist Coalition in what has come to be one of the saddest historical events in Nigeria, Naomi Ndifon (2020) had this to say:

History is timelessly unkind to women and women's contributions to politics and activism. When honor is due to be awarded, Black women's accomplishments are at best, credited to the patriarchs, and at worst, labeled subversive. Therefore, there is a need for us as Black women to tell our stories and document our history before they get the chance to be erased... At the forefront of this [EndSARS] revolutionary youth-led movement against police brutality in Nigeria is the Feminist Coalition - a group of young Nigerian feminists collectively mobilizing all facets of the global \#EndSARS protests... These women, named and unnamed, are the backbone of this resistance. By marching, volunteering, mobilizing, tweeting, speaking, donating, and flagrantly 


\section{6th International Conference on New Findings ON HUMANITIES AND SOCIAL SCIENCES}

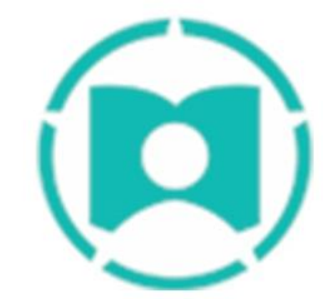

20 - 22 August 2021

Dublin. Ireland trampling on sexist, queerphobic, and transphobic politics, they are, without a doubt, the amplifiers of this historical Nigerian revolution.

As apt as these statements on the empowering contribution of Feminist Coalition and female activists might be, due to the gender taboos and stereotyped standards by which the Nigerian society contemporarily operates, not many share this sentiment.

\section{Conclusion}

In this article, I concentrated on one image - the yellow-black, feminist-oriented \#EndSARS logo - positioning it as the central source around which to discuss the current status of gender relations in contemporary Nigeria. It was ascertained from the study that, regardless of whatever matriarchal structure existed in pre-colonial Nigeria, the contemporary situation, as evidenced through the analysis of the reception of the feminist-oriented logo, is pretty much patriarchal. The practice and display of patriarchy in contemporary Nigeria, however, has a different tenor from what obtained in the past. The current manifestation of patriarchy in Nigeria is shrouded in layers of seeming objectivity and a supposed defence of gender neutrality, a term that, in itself, is used to explain away the reservation of Nigerians towards vehement, feminist or LGBTQIA+ activism. I opine that this subtle form of patriarchy is because of modernisation and the consequent increase in education, globalisation and technological advancement like the current utilisation of social media in online activism. This, added to the fact that more women are engaged in work outside the domestic space of home and are allowed to venture into economic and professional occupations erstwhile believed to be solely for males like military service, engineering, politics etc., might have generated an illusional facade of progressive awareness and equality in terms of gender relations in Nigeria. However, as the analysis of the reception to the logo and other related written and visual representations show, gender stereotypes, standardised binarisation and patriarchy still abound in Nigeria, and, till date, they contend with the efforts of change in the various sectors of the Nigerian society (Dogo, 2014). If the fierce contestations over the needed propriety of gendered visual culture in such a seemingly revolutionary movement as \#EndSARS are anything to go by, then it would seem that the ready acceptance of socially-constructed, performative gender norms is not about to change anytime soon.

\section{References}

Aceng \#EndSARS. (2020, October 23). @ireaderinokun Wow are you okay, we've not question

the symbol. Never intended to. Feministic or not, never mattered to us. Man or woman, we both were victims of brutality and death. Why this coming when we supposed to be United more than ever. Even the statue of liberty is a woman, who cared? [Tweet]. @OceeAnaeme. https://twitter.com/OceeAnaeme/status/1319658289416802305 


\section{6th International Conference on New Findings ON HUMANITIES AND SOCIAL SCIENCES}

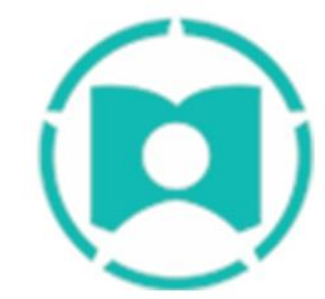

20 - 22 August 2021

Dublin, Ireland

Ademolu, Edward Adedamola Adeleke. (2018). Rethinking Audiences: Visual Representations of

Africa and the Nigerian Diaspora [The University of Manchester]. https://search.proquest.com/openview/7c00bed8e6c61950701a73a7ba615b0f/1?pqorigsite $=$ gscholar $\& \mathrm{cbl}=2026366 \&$ diss $=\mathrm{y}$

Amnesty International. (2020). Nigeria: Killing of \#EndSARS protesters by the military must be

investigated. https://www.amnesty.org/en/latest/news/2020/10/killing-of-endsarsprotesters-by-the-military-must-be-investigated/

ASM. (2018, June 27). @ AishaYesufu jakka! This is not how Muslim women should behave. $\mathrm{Da}$

hijab kike cakume namiji https://t.co/TXoK0v56yw [Tweet]. @SAD333Q. https://twitter.com/SAD333Q/status/1012012677403725824

Bleeker M. et al (2013). Artistic Representation: Women and/in Medieval Visual Culture. In Kim

M. Phillips \& Linda Kalof (Eds.), A Cultural History of Women 2: A Cultural History of Women in the Middle Ages (pp. 179-214). Bloomsbury.

Bloodybelly $\bigcirc$. (2020, October 14). Nigerians are homophobic and rights for LGBQ people are

trash in Nigeria, and we will table that one in its own time, but please, it is wrong for LGBQ people or LGBQ groups to hijack the \#EndSARS protest for their own cause. Bringing your own flags etc divides the campaign focus [Tweet]. @sugabelly. https://twitter.com/sugabelly/status/1316410794452680709

Bredekamp, H. (2013). Theorie des Bildakts (3rd ed.). Suhrkamp.

Chamberlain, M. E. (1974). The Scramble for Africa (P. Richardson, Ed.). Longman Group.

Chú. (2018, June 27). @dashmya @_kiisii_@AishaYesufu Her action is an insult and a mockery of the hijab. Part of the attributes of the hijab is MODESTY, MORALS and DECENCY, of which none of those was displayed over there. Next time remove the hijab and tie it round your waist Ma, then the police will know you're not joking. [Tweet]. @Officially_YM. https://twitter.com/Officially_YM/status/1012020801309233154

Cowling, L., \& Hamilton, C. (Eds.). (2020). Babel Unbound: Rage, reason and rethinking public

life. Wits University Press. https://doi.org/10.18772/22020055898

Davis, W. (2003). Gender. In Robert S. Nelson \& Richard Shiff (Eds.), Critical Terms for Art History (2nd ed., pp. 330-344). Chicago University Press.

Dogo, S. A. (2014). The Nigerian Patriarchy: When and How. Journal of Cultural and Religious

Studies, 2(5). https://doi.org/10.17265/2328-2177/2014.05.002

Dreamstime. (2020). Gender symbols stock vector. Illustration of isolated-14593053. Dreamstime. Retrieved November 12, 2020, from https://www.dreamstime.com/stock-photosgender-symbols-image14593053

E B I T U ${ }^{\mathrm{TM}}$. (2020, October 12). Dear@Google@GoogleDoodles, This shouldn't be difficult 


\section{6th International Conference on New Findings ON HUMANITIES AND SOCIAL SCIENCES}

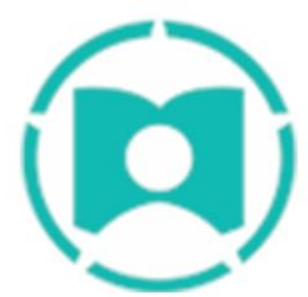

20 - 22 August 2021

Dublin, Ireland for you guys to do, this is all we are asking for! \#SARSMUSTEND 빼 https://t.co/tO0U6kBf6m [Tweet]. @EbituPromise. https://twitter.com/EbituPromise/status/1315575329583398913

Elyse, M. (2013). What Do Our Gender Symbols Really Mean? UMKC Women's Center. https://info.umkc.edu/womenc/2013/06/25/what-do-our-gender-symbols-really-mean/ Feminist Coalition. (2020). Feminist Coalition: Our \#EndSARS fight is also for homosexuals, transgenders. https://lifestyle.thecable.ng/feminist-coalition-our-endsars-fight-is-alsoforhomosexuals-transgenders/

Giwa, S., Logie, C., Karki, K., Makanjuola, O., \& Obiagwu, C. (2020). Police violence targeting

LGBTIQ+ people in Nigeria: Advancing solutions for a 21st century challenge. 36-49. https://doi.org/10.21100/gswr.v1i1.1108

HU\$TLER. (2020, October 23). @ireaderinokun You see the problem?? We respected your idea

as a creative and a youth, but you with your hands is spoiling the whole thing and is casting yourself, you see why a woman can't rule yeah???? You succeeded in doing what you like and people accepted now you've casted it \#dumb [Tweet]. @nooozshmg. https://twitter.com/nooozshmg/status/1319623233063321603

Instablog9ja (@instablog9ja)•Instagram photos and videos. (n.d.). Retrieved December 11, 2020, from https://www.instagram.com/p/CIoMexnrgHJwEpcDBv7yExep31mIi2DyGCjdac0/ Ire Aderinokun. (2020, October 23). On another note, it was honestly so heartwarming to see how this logo I designed in less than 30 minutes and under so much pressure became such a powerful symbol in the movement $\mathbb{W}+$ it was hilarious that misogynists thought the female symbol in it was "hidden" https://t.co/EHpGUEPyG2 [Tweet]. @ireaderinokun. https://twitter.com/ireaderinokun/status/1319548115318378497

KelechiAmadi-Obi (@kelechiamadiobi)•Instagram photos and videos. (n.d.). Retrieved November 12, 2020, from https://www.instagram.com/p/CGSsMM-h0TT/

Ndifon, N. (2020). Nigerian Women vs SARS: A Coalition Against Police Brutality. Black Women Radicals. https://www.blackwomenradicals.com/blog-feed/nigerian-womenvs-sars-a-coalition-against-police-brutality

Nigeria's End Sars protests, in pictures. (2020, October 21). BBC News. https://www.bbc.com/news/in-pictures-54632065

Ogbomo, Onaiwu. (2005). Women, Power and Society in Pre-colonial Africa. Lagos Historical Review, 5, 46-74.

Okonjo, J. (2020). Why Nigerians Are Blowing Hot About \#EndSars Logo (Photos). Longevity. https://vocal.media/longevity/why-nigerians-are-blowing-hot-about-end-sars-logophotos

Oloyede, F., \& Elega, A. (2020). Exploring Hashtag Activism in Nigeria: A Case of \#Endsars Campaign.

Omadjohwoefe, O. S. (2011). Gender Role Differentiation and Social Mobility of Women in $\begin{array}{llll}\text { Nigeria. Journal of Social } & \text { Sciences, } & \text { 27(1), 67-74. }\end{array}$ https://doi.org/10.1080/09718923.2011.11892907 


\section{6th International Conference on New Findings ON HUMANITIES AND SOCIAL SCIENCES}

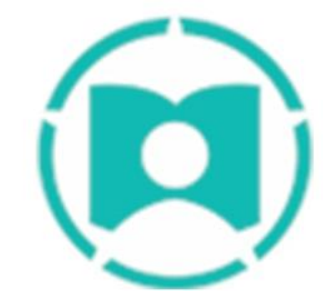

20 - 22 August 2021

Dublin, Ireland

Otutubikey Izugbara. (2004). Patriarchal Ideology and Discourses of Sexuality in Nigeria. African Regional Sexuality Resource Centre.

Oyewumi, O. (1998). Making History, Creating Gender: Some Methodological and Interpretive

Questions in the Writing of Oyo Oral Traditions. History in Africa, 25, 263-305. JSTOR. https://doi.org/10.2307/3172190

Royalty. (2020, October 18). When you have a collective agenda, please stick to it. A selfish move ruins everything. Anyways, just like the work of salvation; everything was paid in full. So, if the devil has any place in your life, you gave it to him. If we derail \#EndSARS, we did it to ourselves. [Tweet]. @royaltyuso. https://twitter.com/royaltyuso/status/1317916570652430337

Scott, J. W. (1986). Gender: A Useful Category of Historical Analysis. The American Historical Review, 91(5), 1053-1075. https://doi.org/10.2307/1864376

SEGA L'éveilleur®@. (2020, October 18). Kindly call this what it is. This is NOT \#EndSARS Movement but an LGBTQ+ and Feminist Movement. Stop impersonating \& exploiting the vulnerability of Nigerians, who genuinely wants to end impunity. This agenda is dead on arrival. There is no place for insurrection in Nigeria! [Tweet]. @ segalink. https://twitter.com/segalink/status/1317907027843256323

TheBaejiri. (2020). (20) Margarita Mama (@TheBaejiri) / Twitter. Twitter. https://twitter.com/TheBaejiri

Ugo jesse (@ugojesse)•Instagram photos and videos. (n.d.). Retrieved November 12, 2020, from https://www.instagram.com/p/CGlOqbPnKBg/

Ukpe, W. (2020, October 25). \#EndSARS: A day by day timeline of the protest that has brought Nigeria to its knees. Nairametrics. https://nairametrics.com/2020/10/25/endsarsprotest-a-timeline-of-all-the-major-events-from-october-3rd/. 